\title{
Reconsidering Constitutional Formation - The Polish May Constitution 1791 as a masterpiece of constitutional communication
}

I. Introduction. The Polish May Constitution ${ }^{1}$ - which was decreed five months before the French September Constitution - is formally the "first constitution of Europe ever". ${ }^{2}$ As the endpoint of the Polish reform movement that set itself the goal of incapability in the inside and independence in the outside ${ }^{3}$ since the $18^{\text {th }}$ century differs from the American constitution of 1787 and the French constitution of 1791 by not creating legitimating foundations of modern statehood after a revolutionary caesura with governing structures

${ }^{1}$ Speech at the XXV. Polish Legal Historians' Conference, held at the University of Cracow 2014. Framework Programme. "Ideas", ERC, Advanced Grant ReConFort, Reconsidering Constitutional Formation. Constitutional Communication by Drafting, Practice and Interpretation in $18^{\text {th }}$ and $19^{\text {th }}$ century. This project has received funding from European Union's Seventh Framework Programme for research, technologica development and demonstration under grant agreement no. 339529. The author ows thanks to Dr. Ania Tarnowska, post doc in ReConFort, for translating the Polish summary and to Prof. Andrzej Dziadzio for his engagement in the advisory board of ReConFort. The constitutional text is published in Polish, Letvian and English and introduced by J. Bardach, Konstytucja 3 Maja 1791, Warszawa 2001 and in German by D. Willoweit, U. Seif, Europäische Verfassungsgeschichte, Munich 2003, pp. 281 et seq. Texts and selected literature can be found at A. Tarnowska, Polskie dokumenty konstytucyjne 1790-1848/Polish Constitutional Documents, Munich 2008, many consecutive references, e.g. J. Kasparek-Obst, The constitutions of Poland and of the United State. Kinship and genealogy, The American institute of polish culture, Miami/Fla. 1980; R.R. Ludwikowski/William et seq. Fox, jr., The beginning of the constitutional era. A bicentennial Comparative Analysis of the First Modern Constitutions, Washington, 1993; Die polnische Verfassung vom 3. Mai 1791 vor dem Hintergrund der europäischen Aufklärung, published by H. Reinalter, P. Leisching, Frankfurt a.M. 1997.

2 D. Gosewinkel, J. Masing, Die Verfassungen in Europa 1789-1949, Munich 2006, pp. 21.

3 C. Dany, Les idées politiques et l'esprit public en Pologne à la fin du XVIII siècle. La Constitution du 3 Mai 1791, Paris 1901, pp. 27 et seq.; Constitution and Reform in Eighteenth-Century Poland. The Constitution of 3 May 1791, ed. S. Fiszman, Bloomington/Indianapolis 1997, with contributions Nr. 1, 2, 4, 5, 6, 8, 11. 
as the ones of the English mother land of the American colonies or the ancien regime. ${ }^{4}$ It is not only since the second and third separation of Poland $(1793 / 95)$ that the constitution was missing the notion of a nation in the sense of the political mobilised people. The 1791-text already does not establish a Polish law of citizenship. The principles of the equality of the citizens and the political equality as well as a proclamation of the fundamental rights were missing. Only the freedom of religion and of culture was mentioned in Art. 1 in the context of the fixation of Roman Catholicism as the state religion. ${ }^{5}$

The influence of the American constitutional movement on the Polish constitutional discussion during the Great or Four-Year Sejm (Sejm Wielki or Czteroletni) 1788-1792 documents the cultural coherence of the Polish $18^{\text {th }}$ century with the European Enlightenment ${ }^{6}$ which is also reflected by the Polish state of the art. $^{7}$ Furthermore, in the press of the Reichstag, the American role model underlines the Polish constitutional motive of documenting independence from the insatiable neighbour and thereby leads to the thesis of the creation of a constitution as an act of the communication of governance. ${ }^{8}$

${ }^{4}$ Compare M. Kirsch, Monarch und Parlament im 19. Jahrhundert, Der monarchische Konstitutionalismus als europäischer Verfassungstyp - Frankreich im Vergleich, Göttingen 1999, pp. 201. This evolutionary character also applies to the constitutional documents after the revolutionary struggles in America (1775-1789) and in France (1789-1795), compare U. Müßig, Konflikt und Verfassung, in: Konstitutionalismus und Verfassungskonflikt, published by the same, Tübingen 2006, p. 6.

5 Concerning the influence on Art. 1 of the Statuto Albertino 1848 compare Kirsch (as annotation 4), p. 133.

${ }^{6}$ Thus, this dissertation thankfully acts on the suggestion of S. Salmonowicz, Rez. zu Müßig, Verfassungsdiskussion, RHD 86 (2008), 590-592. Critical N. Davies, Im Herzen Europas, Geschichte Polens, Munich 2001, pp. 309 et seq. Concerning the cultural coherence compare Pierwsza w Europie, 200 rocznica konstytucji 3 maja 1791-1991, published by H. Kocój, Katowice 1989, pp. 9 et seq., pp. 27 et seq.; J. Kowecki, Sejm Czteroletni i jego tradycje, Warszawa 1991, pp. 11 et seq; J. Łojek, Geneza i obalenic Konstytucji 3 Maja, Lublin 1986, pp. 15 et seq.; the same, Ku naprawie Rzeczypospolitej, Konstytucija 3 maja, Warszawa 1996, pp. 32 et seq.; The Polish constitution of May 3, 1791 before the background of the political enlightenment, published by H. Reinalter, P. Leischnig, Frankfurt/a.M. and others 1997; J. Skowronek, Wielka chwila narodowych dziejów, Konstytucja 3 maja i reformy Sejmu Czteroletniego, Warszawa 1991.

7 Davies (as annotation 6), pp. 309 et seq.; V. Kalinka, Der vierjährige polnische Reichstag 1788-1791, vol. 1, Berlin 1886, pp. 13 et seq.; B. Leśnodorski, Dzieło Sejmu Czteroletniego 17881792. Studium historyczno-prawne, Wrocław 1951, pp. 132 et seq.; the same, Les Institutions Polonaises au Siécle des Lumières, Varsovie 1963, pp. 31 et seq.; E. Rostworowski, Ostatni król Rzeczypospolitej, Geneza i upadek Konstytucji 3 Maja, Warszawa 1966, pp. 27 et seq.; W. Smoleński, Ostatni rok Sejmu Wielkiego, 2. Edition, Kraków 1897, p. 10; W. Sobociński, Polnische Version des Wohlfahrtsstaates vom Ende des 18. Jahrhundert. System des politischen Rechts von 1780 (Archivum Iuridicum Cracoviense X, 1977, pp. 43-80); A. Walicki, The Idea of Nation in the Main Currents of Political Thought, in: Constitution and Reform in Eighteenth-Century Poland, ed. S. Fiszman, Bloomington/Indianapolis 1997, pp. 155-174 (155).

${ }^{8}$ E. Tenzer, B. Pleitner, Polen, in: Handbuch der europäischen Verfassungsgeschichte im 19. Jahrhundert, published by P. Brand, M. Kirsch, A. Schlegelmilch, vol. 1, Bonn 2006, pp. 546-600 (557). 
The latter is furthermore supported by the American struggle for freedom being used as a rhetorical arsenal of both the "patriotic" reform powers as well as the "old-Republican constitutional opponents" in the different press organs. This is proved by the indefiniteness of the constitutional terms of liberty and sovereignty as well as its openness for the elaboration of the political practice. The legal fixation of the political order in a positive constitutional law is not static but translates the ways of thinking and perspectives in the sense of Burkhardt: rule only functions with the consent of the subject. The constitution becomes an "evolutionary achievement" and is the result of the "interplay of the constitutional text, the social contest, the political practice and the constitutional interpretation". ${ }^{10}$ The understanding of the creation of a constitution as an act of communicated governance captures the process-based nature of the constitutional ordering procedures of the creation and limitation of power. The institutional-historical constitutional historiography is thereby overcome. But it is not only the contemporary idea of law that is expressed by the political practice and the constitutional interpretation that contribute to an evolutionary constitutional understanding but also the mutual influence of the constitutional development in the different states. ${ }^{11}$ Thus, the American Revolution may have had a great influence on the constitutional deliberations of the Great or Four-Year Sejm (Sejm Wielki or Czteroletni) of 1788-1792.

The following observations concerning the Polish May Constitution support such an evolutionary constitutional understanding as it was outlaid above:

1. In the tradition of the pre-revolutionary estates-based state, the Polish constitution of May 1791 just after its preamble formulates a constitutional contract between the estates' assembly representing the nation on the one side and "Stanistaw August by the Grace of God through the will of the nation King of Poland" on the other. The constituent nation in the sense of the preamble is not meant to be understood as the sovereign people of free and equal citizens but - and this is in accordance with the old-estate understanding of the nobility as "the furthermost pillar of liberty and the contemporary constitution" 12

9 N. Luhman, Verfassung als "evolutionäre Errungenschaft” RJ 9 (1990), 176-210.

10 D. Grimm, Gewaltengefüge, Konfliktpotential und Reichsgericht in der Paulskirchenverfassung unter besonderer Berücksichtigung des Reichsgerichts, in: Konstitutionalismus und Verfassungskonflikt, published by U. Müßig, Tübingen 2006, pp. 257 et seq.

${ }^{11}$ Brunner's understanding of the constitution as "concrete general state of political unity and the social order if a certain state" (O. Brunner, Land und Herrschaft, unchanged newly printed $5^{\text {th }}$ edition, Wien/Wiesbaden 1990, p. 111) excluded a comparative work. Compare concerning the perspective on the history of state power W. Reinhard, Eine vergleichende Verfassungsgeschichte Europas von den Anfängen bis zur Gegenwart, 2. Edition, Munich 2000.

${ }^{12}$ Art. 2 at the end, cited in Willoweit, Seif (as annotation 1), p. 283. 
- as the nation of the nobility. ${ }^{13}$ The affirmation of the old-Republican pacta conventa in Art. 7 perfectly fits into the picture. ${ }^{14}$

2. Viewed from a different angle, the Polish May constitution is also very impressive for the procedural openness of the making of a constitution. This applies to the side by side of legal and parliamentary ministerial responsibility. As "father and head of the nation", the monarch is not responsible. The ministers appointed by the king assume legal responsibility for the decrees issued by the king by means of counter-signature. Moreover, in Art. 7, the May constitution fixes a parliamentary vote of no confidence which resembles the American impeachment requiring a two thirds majority: "In the case, by contrast, that both chambers united in the Reichstag demand the resignation of a minister from the state council or another position by means of a two thirds majority of secret votes, the King shall be held to most immediately appoint another to this position". ${ }^{15}$ Elsewhere, I already fought against the tendency to view a contrast between constitutionalism and parliamentarism ${ }^{16}$ which is especially popular within German science. ${ }^{17}$ What is important is the correction that Art. 226 of the Spanish Cadiz-Constitution 1812 which insofar does not assume any special position. ${ }^{18}$

3. Another aspect is the elaboration of the executive in Art. 7 with the separation of the hereditary monarch ${ }^{19}$ and the state council which was referred

${ }^{13}$ In the introduction and Art. 2 of the May constitution, the meaning of nation is equivalent to nobility.

${ }^{14}$ Art. 7, cited in Willoweit, Seif (as annotation 1), p. 287.

15 Art. 7, cited in Willoweit, Seif (as annotation 1), p. 289. About the appreciation as parliamentary vote of no confidence compare J. Malec, Rec. on Nationale und Internationale Aspekte der polnischen Verfassung vom 3. Mai 1791, published by R. Jaworski, in: Ius Commune 22 (1995), 431, 433; Tenzer, Pleitner (as annotation 8), pp. 546-600 (567). A.A. K. v. Beymes, Die parlamentarischen Regierungssysteme in Europa, 2. Edition, Munich 1973, pp. 49 et seq.

${ }^{16}$ O. Hintze, Das monarchische Prinzip und die konstitutionelle Verfassung (1911), in: the same, Staat und Verfassung. Gesammelte Abhandlungen zur allgemeinen Verfassungsgeschichte, published by G. Oestreich, 2. Edition, Göttingen 1962, pp. 359 et seq.; E.R. Huber, Deutsche Verfassungsgeschichte seit 1789, vol. 3, 2. Edition, Stuttgart/Berlin/Köln 1978, pp. 3 et seq.; the same, Das Kaiserreich als Epoche verfassungsstaatlicher Entwicklung, in: Handbuch des Staatsrechts, published by J. Isensee, P. Kirchhof, vol. 1, 3. Edition, Heidelberg 2003, § 4 Rd nr. 52 et seq.; E.-W. Böckenförde, Der deutsche Typ der konstitutionellen Monarchie im 19. Jahrhundert, in: Beiträge zur deutschen und belgischen Verfassungsgeschichte im 19. Jahrhundert, published by W. Conze, Stuttgart 1967, pp. 70 et seq. Also J.-D. Kühne, Die Reichsverfassung der Paulskirche, Vorbild und Verwirklichung im späteren deutschen Rechtsleben, 2. Edition, Neuwied and others 1998. Concerning the state of the art E. Fehrenbach, Verfassungsstaat und Nationenbildung 1815-1871, Munich 1992, pp. 71-75 and 75-85.

17 Müßig, Konflikt und Verfassung (as annotation 4), pp. 11 et seq.; U. Müßig, Die europäische Verfassungsdiskussion des 18. Jahrhunderts, Tübingen 2008, pp. 127 et seq.; U. Seif, Einleitung, in: D. Willoweit, U. Seif (as annotation 1), p. XXXII.

${ }^{18}$ Differently Müßig, Die europäische Verfassungsdiskussion des 18. Jahrhunderts (as annotation 17), p. 83.

19 Successor to Stanisław August II. Poniatowski is supposed to be a hereditary monarch from the Wettiner. After their extinction, the right to vote a new monarch falls back to the nation. 
to as straż praw (guardian of the rights) in accordance to Montesquieu's dépôt des lois. The constitutional terminology of ,the King in his state council” is proved by individual interpreters with the association of the English wording of ,the king in council" ${ }^{20}$ The state council which is subordinate to the laws and is to supervise the authorities consisted of the archbishop of Gnesen as primas of Poland, five ministers ${ }^{21}$ as well as two secretaries who had no right to vote and was furthermore headed by the King. The monarch is not responsible before the state council.

4. The elaboration of the two chamber legislative body which was separated from the executive ${ }^{22}$ and made up of the Messengers' Chamber and the Senators' Chamber also shows potential for evolutionary development. While the Messengers' Chamber was supposed to be "the sanctuary of the legislature as the representative body and embodiment of national sovereignty", ${ }^{23}$ the Senators' Chamber which was governed by magnates and headed by the King had a suspensive veto against the resolutions of the Messengers' Chamber. By contrast to the American constitution, the House of Representatives was dominating. If after the veto of the Senate, the same law was passed again by the House of Representatives, it was valid irrespective of the Senate's veto. The King possessed a single vote in the Senate; he did not have the right to veto by means of his chair. As was the case in the French September constitution, the King had a right of legislative initiative, the same applying to the messengers. Besides the 204 representatives of the nobility, 24 citizens were part of the Messengers' ${ }^{6}$ Chamber as commissioners of the royal cities. As representatives of the nation as a whole (Art. 6), the representatives from the (provincial) state parliaments were no longer dependent whereby the metamorphosis from an estate organ towards a modern representative institution can be observed. The estate-based perception of an imperative mandate turns into the conviction of the individual freedom of decision of the state citizen who is obliged to the general good. The majority principle was applied in both legislative bodies. Liberum veto and the confederate right were abolished. ${ }^{24}$

${ }^{20}$ Z. Libiszowska, The Impact of the American Constitution on Polish Political Opinion in the Late Eighteenth Century, in: Constitution and Reform in $18^{\text {th }}$-Century Poland, ed. S. Fiszman, Indiana Univ. Press 1997, pp. 233 et seq.

${ }^{21}$ Police/Interior affairs; exterior affairs; defense; justice; finances.

22 Art. 5 of the May constitution separates the executive power of the hereditary monarch and the one of the state council from the legislative power of the Reichstag as two chamber legislative body made up of the Messengers' Chamber and the Senators' Chamber and from the jurisdiction of the existing courts (cited in Willoweit, Seif, as annotation 1, p. 284). Compare Art. 7 and the explicit separation of the executive and legislative power: "The executive power shall not pass any laws, no taxes whatsoever, no state derivatives, not change the state income, not declare any war, no freedom, no contract and no diplomatic acts" (cited in Willoweit, Seif, p. 286).

${ }^{23}$ Art. 6, cited in Willoweit, Seif (as annotation 1), p. 284.

${ }^{24}$ Art. 6 at the end cited in Willoweit, Seif (as annotation 1), p. 286. 
5. It was not only in the case of the fixation of parliamentary ministerial responsibility but also in the case of constitutional supremacy that the May constitution assumed a pioneering role. It is the only constitutional document of the revolutionary era that expressly articulates constitutional supremacy by stating that "all consecutive resolutions of the current sejm are to be consistent with the constitution in all respects" (ending of the introduction). The evolutionary character of such a declaration becomes even more evident when considering the importance of the constitutional body. Although the Polish May constitution does not systematically fix the conditions of legitimacy after a revolutionary caesura as "the basis and foundation of government" in the wording of the Virginia Bill of Rights $1776^{25}$ or as "le but de toute institution politique" in the wording of the declaration of human civil right as it is found in the September constitution $1791,{ }^{26}$ it fixes a core part of normativity and a positive uniform constitutional text due to the notion of constitutional supremacy.

- And that, although the constitutional text of the American role model does not mention constitutional supremacy. ${ }^{27}$ In the Federalist paper ${ }^{28}$ which are widely read in Poland, constitutional supremacy is legitimised in Art. 85

25 Compare "le but de toute institution politique" in the diction of the preamble of the Declaration of human and civil rights 1789 (cited in Willoweit, Seif, as annotation 1, p. 250).

${ }^{26}$ Cited in Willoweit, Seif (as annotation 1), p. 251.

27 Since the decision of Marbury v. Madison (5 U.PP. (1 Cranch) 137 (1803)), the competence of the Highest Federal Court for the constitutionality of the laws of Congress is recognized. As answer to H. Dippel (Archiv für Sozialgeschichte 49 [2009], http://library.fes.de/fulltext/afs/ htmrez/81038.htm) it has to be mentioned that the accountability of the American President to Congress according to Art. 2 Sec. III Constitution 1787 (Willoweit, Seif, as annotation 1, p. 271) was designed as a right of influence of the President on the legislative procedure (compare B. Schwartz, A Commentary on the Constitution of the United States, Part I Powers of Government - vol. II, New York 1963, p. 27; E. et seq. Cooke, A Detailed Analysis Of The Constitution, Totowa (NY) 1984, p. 90). This contains the submission of the elaborated bills and the convocation of an assembly of both chambers (compare E. Dumbauld, The Constitution of the United States, University of Oklahoma Press 1964, pp. 310, 312). The literature concludes a duty of the president to submit Congress all relevant literature for the legislative procedure (Dumbauld, ibid., p. 311; Schwartz, ibid., p. 27). Dippel's criticism is also not understandable concerning the suspensive veto of the American President according to Art. 1 Sec. VII (Willoweit, Seif, as annotation 1, pp. 261 et seq.). Since the presidential veto required a new discussion and adoption, the exercise of the veto has a suspensive effect (compare Schwartz, ibid., pp. 30,31; Cooke, ibid., pp. 52). Since the electoral college members in contrast to Art. 2 Sec. 1 (Willoweit, Seif, as annotation 1, pp. 267) proclaimed whom they were going to vote for as (vice) President, the people in fact elected their favourite candidate directly (Dumbauld, ibid., p. 264; Cooke, ibid., p. 78; Schwartz, ibid., p. 9; C.H. Pritchett, The American Constitutional System, New York 1971, p. 45). Dippel's last point of criticism concerning my depiction of the American constitution (Müßig, Die europäische Verfassungsdiskussion (as annotation 17) pp. 27 et seq.) is not justified either. Due to the judge-made established competence of normative control of the highest federal court, it goes without saying that the American constitutional text even in its nowadays version does not fix an abstract review of statutes.

28 A. Hamilton, J. Madison, J. Jay, The Federalist Papers, Buccaneer Books, Cutchogue N.Y. 1992, pp. 266 et seq., pp. 340 et seq., pp. 392 et seq. 
by declaring it the last measurement for the acting of political powers. The constitution does not only define a political order capable of assuring liberty and property but also the only system being able to assure the existence of the nation. By contrast to the English linguistic usage, during the American revolution, the terminological differentiation between the constitution and other law is developed, ${ }^{29}$ the political revolution being understood as righteous breach of law. ${ }^{30}$ Although the old constitutional semantics knew especially important and fundamental laws ${ }^{31}$ it did not inhibit the idea of a uniform law that was to be the measurement of the lawfulness of all other laws: "...in a Republic where the Law is superior to any or all the Individuals, and the Constitution superior even to the Legislature, and of which the Judges are the guardians and protectors." formulated James Iredell in his "Instructions to Chowan County Representatives" (1783). ${ }^{32}$ Thanks to the new terminology, it is possible to declare certain acts "unconstitutional": "Therefore the terms constitutional and unconstitutional mean legal and illegal". 33 "Unconstitutional" was the taxation of the colonies by the London Parliament without the consent of the inhabitants (Sugar Act ["American Duties Act" 1764];34 Stamp Act ["Duties in American Colonies Act" 1765] $]^{35}$ ), "constitutional", however, was the resistance of the colonies. ${ }^{36}$ The broad effect of the adjective "unconstitutional" was based on the Americans endeavour - to be more loyal to the constitution than the English - to justify their resistance by reference to the British constitution and to legitimize the revolution as legal breach of the law. ${ }^{37}$ This argumentation of the American revolutionaries was, from a Polish point of view, suitable to legitimize the resistance against the divine right of

${ }^{29}$ G.S. Wood, The Creation of the American Republic 1776-1787, Chapel Hill N.C. 1969, p. 260. In 1789, France makes use of the English term "constitution" including all of its ambiguity and then even discusses the necessary amount of the separation of powers.

${ }^{30}$ In America, the revolution is legally justified with the medieval idea that the sovereign the London parliament - may not commit any breaches of the law, otherwise a right of resistance of the people being triggered. This right of resistance of the people against parliament then had to be transformed into a legal order that excluded exactly that for future cases.

${ }^{31}$ Concerning their supremacy by the "Council and the consent of the great" see Seif, Einleitung, in: Willoweit, Seif (as annotation 1), pp. XII et seq.

${ }^{32}$ Cited in accordance with The Papers of James Iredell, ed. D. Higginbotham, Raleigh 1976, vol. II, p. 449.

33 W. Paley, The Principles of Moral and Political Philosophy (1785), cited in accordance with W. Paley, The Works, London/Edinburgh 1897, p. 114.

${ }^{34}$ American Duties Act vom 5.4.1764, in: 4 George III, c. 15.

35 Duties in American Colonies Act of 22.3.1765, in: 5 George III, c. 12

36 "Therefore the terms constitutional and unconstitutional mean legal and illegal." (W. Paley, The Principles, as annotation 33, p. 114). Compare G. Stourzh, Constitution: Changing Meanings of the Term from the Early Seventeenth to the Late Eighteenth Century, in: Conceptual Change and the Constitution, ed. T. Ball, J.G.A. Pocock, Lawrence/Kansas 1988, pp. 35, 45 et seq.; G. Wood, The Creation of the American Republic 1776-1787, Chapel Hill N.C. 1969, pp. 10 et seq.

37 Stourzh (as annotation 36), pp. 35, 45 et seq. 
the Tsarina, the Prussian King and the Habsburg Emperor of the Holy Roman Empire.

\section{Presentation of the American Revolution in the Polish journalism.} "Liberty" and "security" are the key word in the speech of Sejmmarshall Stanisław Małachowski (1736-1809) with which he presents the constitutional draft to the representative chamber on May 3, 1791: ${ }^{38}$ In this century, there were two pivotal Republican constitutions, the English and the American, ours [the Polish] outperforming the two of them; it guaranteed liberty, security and all freedoms. ${ }^{39}$ These associations of Małachowski with the AngloSaxon constitutions mirrors the importance of the English constitutional model and the American constitutional movement in the journalism during the Great or Four-Year Reichstag (Sejm Wielki or Czteroletni) from October 6, 1788 until May 29, $1792 .{ }^{40}$ In the Sejm, two contrary political currents were represented: the conservative old-Republicans as guardians of the "golden liberty" in the sense of the Articuli Henriciani (1572) who were opposed to the Polish constitutional project on the one side and the reform party of the patriots on the other. None of the two had the majority in the Sejm and each was thus dependent on the support of the public which was courted by journalist reports.

In their physiocratic liberal ideas and their Montesquieu understanding of the law, ${ }^{41}$ the patriots sought the support of the Warsaw population by means of the press organs Gazeta Narodowa i Obca and Pamiętnik Historyczno-Polityczny. ${ }^{42}$ In the reports about the Sejm discussions about the rights of participation of the citizen population, the role model of the American society lacking estate differences, play an important role. For instance, the editor of the Pamiętnik Historyczno-Polityczny Piotr Świtkowski discusses the rights of the townspeople in his article about the United States: it was a big mista-

38 Are considered as the editors of the May constitution, Scipione Piattoli, royal secretary, Ignacy Potocki, spokesman of the patriots in the Sejm, Hugo Kołłątaj, since 1791 royal vice chancellor and the monarch himself (compare G.-CH. v. Unruh, Die polnische Konstitution vom 3. Mai 1791 im Rahmen der Verfassungsentwicklung der Europäischen Staaten, in: Der Staat 13 [1974], 185 et seq.; the same, in: Jaworski, as annotation 15, pp. 54 et seq.).

39 Paraphrasing translation of the speech, cited in: Gazeta Narodowa i Obca, no. 37, 7 May 1 1791. It may be due to political calculus that Małachowski does not mention the French Revolution.

${ }^{40}$ Materiały do dziejów Sejmu Czteroletniego [Sources concerning the deeds of the Four-Year Sejm], published by J. Michalski, E. Rostworowski, J. Woliński, vol. 1-5, together with A. Eisenbach, vol. 6, Warszawa 1955-69.

${ }^{41}$ K. Opałek, Monteskiusz w Polsce, in: Monteskiusz i jego dzieło, Wrocław 1956, pp. 239-290; Z. Libera, Problemy polskiego Oświecenia, Warszawa 1969, pp. 27 et seq.

${ }^{42}$ H. Olszewski, Die Maikonstitution als Krönung der polnischen Reformbewegung, in: Jaworski (as annotation 15), p. 31; compare furthermore J. Michalski, Rousseau i sarmacki republikanizm, Warszawa 1977. 
ke to assume that a great nation may be free if all political rights were only exercised by the nobility. In America, it was the personal accomplishment and not noble birth (paraphrased translation) ${ }^{43}$ that counted. The anonymous pamphlet Dwóch nieboszczyków (Two dead men) of 1791 may be read in the same light. By reference to Willhelm Tell and George Washington, it denunciates the error that alone the noble ancestry and not intelligence, accomplishment, ability and virtue were to be hailed (paraphrased). ${ }^{44}$ The same applies to the anonymous pamphlet Dusza Krajów, czyli o poddanych polskich (The sole of the country or about the Polish land people) of 1789: the youngest revolution in America, had awarded George Washington, a until then unknown inhabitant of Virginia, the name of a great general and founder of liberty and the whole world would remember his name with respect (paraphrased). ${ }^{45}$ Julian Ursyn Niemcewicz is even clearer: Nobody of us knows who the father of Washington or the grandfather of Franklin was. (...) But everybody knows and will remember in the future that Washington and Franklin freed America (paraphrased). ${ }^{46}$ The leader of the patriotic reform movement, Hugo Kołłąaj (1750-1812), ${ }^{47}$ who had great influence on the Sejmmarshall Stanisław Małachowski refers to the democratic ideas of Franklin and Washington ${ }^{48}$ in order to justify his commitment for the political participation of the upper bourgeoisie that corresponds to his dedication for the representation of the cities in the Sejm and for the introduction of a modern economic system by creating a national bank.

In the journalistic debate about the economic consequences of the political rights of participation of the townspeople, America does not only serve as

${ }^{43}$ Stan prawdziwy wolnej Ameryki Pótnocnej [The true state in the free North America], Pamiętnik Historyczno-Polityczny, April 1789.

${ }^{44}$ Dwóch nieboszczyków, Dekiert z ministrem o miastach [Two dead men, Dekiert (polish name) to a minister of the towns] (1791) in: Materiaty do dziejów Sejmu Czteroletniego (as annotation 40), published by J. Michalski, E. Rostworowski, J. Woliński, vol. 4, p. 57.

45 Dusza krajów, czyli o poddanych polskich... [The sole of the country or of the Polish townspeople...] (1789) in: Materialy do dziejów Sejmu Czteroletniego (as annotation 40), published by J. Michalski, E. Rostworowski, J. Woliński, vol. 1, p. 545.

${ }^{46}$ Gazeta Narodowa i Obca, no. 27 of March 9, 1791. A selection from Niemcewicz's speech was cited in The Newport Mercury of July 30, 1790. Compare M. Haimann, The Fall of Poland in Contemporary American Opinion, Chicago 1935, p. 35.

${ }^{47}$ Former dean of the University of Krakau and later royal vice chancellor in 1791. Concerning Kołłątaj’s person and oeuvre compare M. Pasztor, Hugo Kolłataj na Sejmie Wielkim w latach 1791-1792, Warschau 1991. H. Kołłątaj, the spiritual cornerstone of the "forge" (Kuźnica), became the reform motor due to its Listy Anonima (1788/90) and a constitutional draft (prawo polityczne narodu polskiego, 1790). The Polish writings of Kołłątajs were newly edited during the $50^{\text {s }}$ by B. Leśnodorski who also wrote an article on Hugo Kołłątaj in: $Z$ dziejów polskiej myśli filozoficznej i spolecznej, vol. 2, Warszawa 1956.

${ }^{48}$ H. Kołłątaj, Uwagi nad pismem... Seweryna Rzewuskiego... o sukcesyi tronu w Polszcze rzecz krótka [Remarks about Seweryn Rzewuski's short essay on the throne succession in Poland], Warszawa 1790, pp. 71-77. 
a role model but as a "country of promise beyond the Atlantic". ${ }^{49}$ The news about the economic boom in North America emphasize the connection with the political liberty (Montesquieu's wording): "voilà les fruits de la liberté, voilà ce que produit un Gouvernement sagement organisé et doué d'énergie." 50

The reference to America is omnipotent as the Journal Hebdomadaire de la Diète which was published by Jan Potocki shows. ${ }^{51}$ The American federal treaty of March 1, 1781 is printed often in the contemporary Polish press. ${ }^{52}$ The constitutional draft of the Philadelphia Convention was published in the Gazeta Warszawska as well as in the Gazety Wilenskie. ${ }^{53}$ Regular reports about the political system and the economic situation were published by Piotr Switkowski on a monthly basis in the Pamiętnik Historyczno-Polityczny. ${ }^{54}$ It was him who presented the principles of the new constitution and the governmental system of the United States of North America in the January edition of the Pamiętnik Historyczno-Polityczny from $1790 .{ }^{55}$ In the Gazeta Narodowa $i$ Obca which is also pro-patriotic, the introductory speech of President Washington in the first Congress is printed in two consecutive editions in January $1791^{56}$ when the Polish constitutional draft was more and more opposed by the old-Republican opposition of conservative noblemen lead by Seweryn Rzewuski (1743-1811). The pro-patriotic Gazeta Narodowa i Obca prints Franklin's praise of the American constitution ${ }^{57}$ in order to advertise for the Polish reform project. ${ }^{58}$ Occasionally, the press reports about America are for-

49 Usprawiedliwienie dysydentów mieszczan ... [A justification of the citizen dissidents...], in: Materiały do dziejów Sejmu Czteroletniego (as annotation 40), vol. 2, p. 90; H. Kołłątaj, "Odezwa do deputacji Konstytucyjnej" [A call on the constitutional deputation], in: Listy Anonima i Prawo polityczne narodu polskiego, published by B. Leśnodorski, H. Wereszycka, Warszawa 1954, vol. 2, p. 180; J. Jezierski, Miasta bez prawa [Cities without rights], Warszawa (Gröll), no year [1791], in: Materiały do dziejów Sejmu Czteroletniego (as annotation 40), vol. 4, p. 51.

${ }^{50}$ Gazeta Narodowa i Obca, no. 4, of January 14, 1791.

51 Journal Hebdomadaire de la Diète, no. 51, of December 26, 1790.

52 Z. Libiszowska, Opinia polska wobec Rewolucji Amerykańskiej w XVIII w. [The Polish understanding of the American Revolution of the $18^{\text {th }}$ century], Łódź-Wrocław 1962, p. 116; compare Stany Zjednoczone pod rzadem Artykułów Konfederacji [The United States under the articles of the confederation], in: Konstytucja USA 1787-1987. Historia i Wspótczesność, published by J. Wróblewski, Warszawa 1987, pp. 52-77.

53 Libiszowska, Opinia polska (as annotation 52), p. 116.

54 American subjects may be found in Pamiętnik Historyczno-Polityczny, January 1790, pp. 42-49, Februar, pp. 1-19, 35-49, 68-80, March, pp. 179-202, April, pp. 276-331, October, pp. 1180-1193, November, pp. 1328-1342, February 1791, pp. 138-153, April, pp. 171-374.

55 P. Świtkowski, "Zasady Nowej Konstytucji i formy Rządu Zjednoczonej Ameryki Północnej" [The principles of the new constitution and governmental forms in the United States of North America], Pamiętnik Historyczno-Polityczny, January 1790.

${ }^{56}$ Gazeta Narodowa i Obca, no. 4, of January 14, 1791.

57 Gazeta Narodowa i Obca, no. 46, of June 8, 1791.

58 [I. Potocki], Na pismo, któremu napis “O Konstytucji 3 Maja 1791.”... odpowiedź [Answer to the publications with the title "About the May constitution 1791"], Gazeta Narodowa i Obca, 
mulated as letters from America - with a clear tenor against the intrigues of the aristocratic opposition. For instance, a letter supposedly originating from Boston opposes the cabinet intrigues, the wars and disagreements in Europe to the wealth, calm and openness in the self-administered and independent United States of America in the Gazeta Narodowa i Obca of May 1791.59 Piotr Świtkowski, too, promotes the acceptance of the Polish constitution with the successful history of America which only until shortly began its political existence under the flag of liberty (paraphrased) in the Pamiętnik Historyczno-Polityczny (paraphrased). ${ }^{60}$ In the same edition, Washington's report to the Congress is printed. ${ }^{61}$ The Gazette de Varsovie follows this example.

Especially during the constitutional deliberations about the Polish governmental system, the allusions to America serve the rhetorical ornamentation since to the general conviction, the American role model was not directly applicable to Poland. Not only the patriotic reform powers but also the old-Republican constitutional opponents make use of the American role model. In his chronological information about the loss of liberty under a hereditary monarch (Wiadomość chronologiczna, w którym czasie, które państwo wolność utraciło pod rządem monarchów sukcesyjnych, 1790), the Field-Hetman and old-Republican and spokesman Seweryn Rzewuski devalues the English hereditary monarch by use of the American struggle for liberty as being incompatible with liberty: The Americans did not have any other option but to fight the English crown (paraphrased). ${ }^{62}$ Franklin and Washington had unmasked the true spirit of the English liberty (paraphrased) ${ }^{63}$ The equation of hereditary monarch and despotism is explained with the English suppression of the American colonies. ${ }^{64}$ According to Rzewuski's essay on the succession to the throne in Poland (O sukcesyi tronu w Polszcze rzecz krótka, 1789), the traditional old-republicanism with elective monarchy and a liberum veto corres-

no. 46, of June 8, 1791. Compare W. Smoleński, Ostatni rok Sejmu Wielkiego [The last year of the Great Diet], Kraków 1897, p. 77.

${ }^{59}$ Gazeta Narodowa i Obca, no. 63, of July 6, 1791.

${ }^{60}$ Stan prawdziwy wolnej Ameryki Pólnocnej [The true state of the free North America] (as annotation 43), p. 1128-1142.

${ }^{61}$ Gazette de Varsovie, no. 19, of June 25, 1792.

${ }^{62}$ [S. Rzewuski], Wiadomość chronologiczna, w którym czasie, które państwo wolność utraciło pod rządem monarchów sukcesyjnych [Chronological information on when and what state lost its liberty due to a hereditary monarch], Warszawa, without a year [1790]. Zofia Zielińska convincingly shows that Rzewuski was himself the author of most of he pamphlets (Republikanizm spod znaku buławy. Publicystyka Seweryna Rzewuskiego z lat 1788-1790 [Republicanism under the Field-Hetmans Streitkolben. Political articles of Seweryn Rzewuski 1788-1790], Warszawa 1991, pp. 23 et seq.

${ }^{63}$ [S. Rzewuski], Uwagi dla utrzymania wolnej elekcyi króla polskiego do Polaków, w Warszawie roku 1789 [Remarks for the Polish on the assurance of free elections of the Polish king].

${ }^{64}$ List $z$ Warszawy do przyjaciela na wieś o projektach Nowey formy Rzadu [A letter from Warsaw to a friend on the countryside about the proposals of a new governmental form], 9 August 1790. 
ponds to American federalism if transferred to Polish circumstances. ${ }^{65} \mathrm{~A}$ few anonymous authors supported Rzewuski's position of the elective kingdom as a guarantee for liberty by reference to the newly founded Republic of America. ${ }^{66}$

Mazzei's correspondence with Stanislaw August II. proves how much the monarch and the reform party feared this old-Republican claim of a free people not needing a king. ${ }^{67}$ Philip Mazzei was Polish representative in Paris since 1788 and was admired by King Stanisław August II. Poniatowski (1764-1795) due to his friendship with Jefferson. ${ }^{68}$ His correspondence which was published in the usual foreign languages is an important source for the Anglo-American role models of the reform positions of the royal court against the principle of unanimity in the Sejm and against the elective competence of the noble state parliaments for the Reichstag. They prove the royal reading and knowledge of the Two Treatises of Government of John Locke and the Federalist Papers. ${ }^{69}$ Stanisław August was acquainted with the contemporary political institutions of England and America ${ }^{70}$ and referred to the separation of powers as a "new theory of governance" 71 with which a strengthening of the executive branch with a hereditary monarch was perceived as compatible. In the royal library, Jefferson's Notes on the State of Virginia, John Dickin-

${ }^{65}$ S. Rzewuski, O sukcesyi tronu w Polszcze rzecz krótka [A short essay on the throne succession in Poland] 1789). Compare Z. Zielińska, Republikanizm spod znaku buławy. Publicystyka Seweryna Rzewuskiego z lat 1788-1790 [Republicanism under Feldhetmans Streitkolben. Political articles of Seweryn Rzewuski 1788-1790], Warszawa 1991, pp. 57 et seq.; "O sukcesyi tronu w Polszcze 1787-1790" [About the succession to the throne in Poland 1787-1790], Warszawa 1991.

${ }^{66}$ [S. Rzewuski], Myśli nad różnemi pismy popierajacymi sukcesya tronu [Thoughts on the different essays on the support of the succession to the throne], 1790.

67 Tenzer, Pleitner (as annotation 8), pp. 546-600 (558). Stanislaw August to Mazzei, 27 January 1790, Mss. Ossolineum no. 9751, p. 16. P. Mazzei, Selected Writings and Correspondance (1788-1791), in: Agent for the King of Poland During the French Revolution, published by M. Marchione, Prato 1983, p. 260.

${ }^{68}$ Libiszowska (as annotation 20). The royal secretary Scipione Piattoli who was a friend of his was also known to Jefferson and well informed on the American legislative procedure (Libiszowska, as annotation 20, p. 233, 234).

69 Stanislaw August to Mazzei, 20 January 1790, Mss. Ossolineum no. 9751, p. 16. Aside from the English version mentioned in annotation 68 of the Mazzei-correspondance, there is an Italian version edited by R. Ciampini (Lettere di Filippo Mazzei alla corte di Polonia [1788-1792], Bologna 1937) as well as J. Michalski and M. Senkowska-Gluck's French version (Lettres de Philippe Mazzei et du Roi Stanislas-Auguste de Pologne [July 1788 until August 1789], Rom 1982).

${ }^{70}$ Compare J. Topolski, Die wirtschaftlichen und sozialen Grundlagen der Reformbewegung in Polen im 18. Jahrhundert, in: Jaworski (as annotation 15), pp. 8-23 (11); compare J. Fabre, Stanislas Auguste Poniatowski et l'Europe des Lumières, Paris 1952.

${ }^{71}$ [M. Wolski], Zdanie o królu polskim 1792 roku [The opinion on the Polish King 1792], in: Rocznik Towarzystwa Historyczno-Literackiego, Paryż 1867, pp. 10-28. Concerning Stanislaw August as the author of this pamphlet E. Rostworowski, Legendy i fakty XVIII w., Warszawa 1963, pp. 488 et seq. 
son's Letters From a Farmer in Pennsylvania, Thomas Paine's The Rights of Man and Joel Barlow's The Vision of Columbus are also proved. ${ }^{72}$ In this context also belong Philip Mazzei's Recherches historiques et politiques sur les Etats Unis de l'Amerique Septentrionale (Paris 1788) with a printed version of the American constitution ${ }^{73}$ and the collection of the treaties between the European powers (Traktaty między mocarstwami europeyskiemi) of the historian Franciszek Siarczyński who therein consecrates a long introduction with a short summary of the American wars of liberation to the federal treaty. ${ }^{74}$ In the last volume of the collection which was published in 1790, he published the constitution of the United States $1787 .{ }^{75}$

The old-Republican praise for the American federalism is deciphered by Hugo Kołłątaj as a call for a "pure noble liberty which inevitably leads to the separation of the country” (paraphrased). ${ }^{76}$ In his „Anonymous letters to Stanisław Małachowski" (1789) $)^{77}$ and in "The political right of the Polish nation (1790)" "78, Kołłątaj favoured a strict Republican constitution which due to the different geographic situation of Poland and America does not contradict a monarchical executive spearhead. Another mentor of the May constitution, Stanisław (Wawrzyniec) Staszic (1755-1826) ${ }^{79}$ answers Rzewuski's polemics with the warning that the (noble) Republic cannot exist between despotic monarchies. ${ }^{80}$ As philosopher and geologist, his interests are found in the scien-

72 Libiszowska (as annotation 20), pp. 233, 234.

${ }^{73}$ P. Mazzei, Recherches historiques et politiques sur les États Unis de l'Amerique Septentrionale, vol. 4, Paris 1788, pp. 181 et seq.

${ }^{74}$ Traktaty między mocarstwami europeyskiemi [Treaties between the European powers], vol. 4, published by F. Siarczyński, Warszawa 1776, pp. 292-306 (printed version of the conferedate article).

75 Traktaty między mocarstwami europeyskiemi [Treaties between the European powers], vol. 6, published by F. Siarczyński, Warszawa 1790, pp. 220-253 (printed version of the American constitution).

${ }^{76}$ Kołłątaj, Uwagi nad pismem... (as annotation 48), p. 66.

77 The letters include Do Stanistawa Małachowskiego Referendarza Koronnego, Marszatka Seymowego i Konfederacji Generalney Anonyma Listów kilka, Część I. O Podźwignięciu Sit Kraiowych. 1788. Od dnia 1 do dnia 24. Sierpnia; Do Stanisława Małachowskiego Referendarza Koronnego, Marszalka Seymowego i Konfederacji Generalney Anonyma Listów kilka, Część II. O Poprawie Rzeczypospolitey. 1788. Od dnia 7 Paźdz. do dnia 7 List. and Do Stanistawa Małachowskiego Referendarza Koronnego, Marszatka Seymowego i Konfederacji Generalney Anonyma Listów kilka, Część III. O Poprawie Rzeczypospolitey. Od dnia 11 Listop. Do dnia 19. Grudnia, Roku 1788. W Warszawie, w Drukarni Uprzywileiowaney Michała Grölla, Księgarza Nadwornego J.K. Mci.

${ }^{78}$ Cited in accordance with Tenzer, Pleitner (as annotation 8), pp. 546-600 (559).

79 S. Staszic influenced the reform discussion immensely with his articles on Uwagi nad życiem Jana Zamoyskiego (1787) and Przestrogi dla Polski (1790) (B. Suchodolski, Art. zu S. Staszic, in: Z dziejów polskiej myśli filozoficznej... vol. 2, Warszawa 1956; W. Goetel, S. Staszic, Kraków 1969). Staszic later became President of the influential society of the friends of science (1808).

${ }^{80}$ S. Staszic, Przestrogi dla Polski [Warnings to Poland], in: Pisma filozoficzne i społeczne, published by B. Suchodolski, vol. 1, Warszawa 1954, pp. 192. 
tific and economic development of the country whose economic misery he decried. ${ }^{81}$ Ignacy Potocki (1751-1809), spokesman of the patriots in the Sejm, regrets that Poland cannot be a general republic or confederation according to the given circumstances but only a constitutional monarchy. ${ }^{82}$ For the patriots, the hereditary monarch as the head of the executive power is owed to the neighbourhood to the separating powers. In the same direction goes a pamphlet Krótka rada względem napisania dobrej konstytucji (Short advice on how to elaborate a good constitution) which was published in 1790 in its paraphrased translation: "Even if a nation has no king, the legislative and executive power have to be separated. Then, the executive power is vested in the administration; the legislative power is vested in the national representatives. This is the situation in the thirteen American provinces... where each province has its own administration, its own courts, its own tax and military and all together have their House of Representatives with their President which only differs from the English King by his name [sic!] and enjoys the executive power and the might to make laws for the whole territory." ${ }^{83} \mathrm{Du}$ ring the Polish reform discussion, the American role model strengthens the conviction that the executive power is best versted in a hereditary monarch. ${ }^{84}$ The United States, a confederation of colonies having gotten rid of George III. were eager to find a surrogate for the king when modelling the presidential office. In his series of essay in Pamiętnik Historyczno-Polityczny, Świtkowski compares the Polish and American constitutional circumstances and draws the reader's attention to the fact that the exterior political threat of Poland demands a strengthening of the executive as well as the introduction of a hereditary monarchy. ${ }^{85}$

${ }^{81}$ Compare concerning Stanislaw Staszic N. Davies, God's Playground, A History of Poland, vol. 1, Oxford 1981, pp. 530 et seq.; J. Topolski, L'Etat dans la pensée politique de Stanislas Staszic 1755-1826, in: L'Etat dans les doctrines économiques et politiques de la Renaissance à nos jours, published by P. Preton, Strasbourg 1990, pp. 99-109.

82 Ignacy Potocki an Eliasz Aloe, 7 August 1790. Mss. Potocki Papers, no. 277 vol. 303, AGAD, Central Archives of Historical Records in Warsaw. Compare Rostworowski (as annotation 72), pp. 323.

${ }^{83}$ [K.] Kwiatkowski, Krótka rada względem napisania dobrej konstytucyi [Short piece of advice on how to elaborate a good constitution], without a place of publication 1790, pp. 28.

${ }^{84}$ Compare concerning the convincing power of the idealised monarchy as it is portrayed in Montesquieu in II,4 De l'Esprit des Lois (Pléiade-Edition, Oeuvres complètes, published by R. Caillois, tome II, Paris 1994, PP. 247 et seq.) CH.-E.-L. Konic, Comparaison des Constitutions de la Pologne et de la France de 1791 (thèse doct. Univ. de Neuchatel), Lausanne 1918, pp. 45 et seq. More generally on II,4 De l'Esprit des Lois compare U. Seif, Der mißverstandene Montesquieu: Gewaltenbalance, nicht Gewaltentrennung, ZNR 22 (2000), 149-166 (157 et seq.).

85 P. Świtkowski, Dalsze myśli i uwagi względem Konstytucji 3 Maja [Further thoughts and remarks on the constitution of May 3], Pamiętnik Historyczno-Polityczny, August 1791, pp. 737-745 . 
The prudence of the American constitutional deliberations ${ }^{86}$ and of the constitutional text ${ }^{87}$ as to the popular sovereign opens the possibility to both the reform powers as well as the reform opponents to refer to the American role model be it for the extension of political participatory rights to the townsmen or the restriction of the Crown by rights of resistance granted to the nobility. ${ }^{88}$ In Art. I, sec. 8 of the American constitution of 1787, the classical rights of sovereignty are vested in the popular representation. ${ }^{89}$ When in 1772 the Committee of Correspondance of the city of Boston for the first time formulates the thought of popular sovereignty, it seems rather owed to the necessity that there sould be limits for Westminster. It is only with the call for popular sovereignty that the parliamentary sovereignty ${ }^{90}$ of the English Houses of Parliament can be rejected ${ }^{91}$ even if the elected colonial representative bodies do not expressly vow for the nullity of disliked parliamentary laws during their protest against the mother land. ${ }^{92}$ In the Polish May constitution, consti-

86 "The real source of danger to the American Constitutions" (James Madison in the meeting of July 2, 1787, cited in: The Records of the Federal Convention of 1787, 3 vol., published by M. Farrand, New Haven 1911, vol. II, p. 74).

${ }^{87}$ Compare the exclusion of direct popular participation when it comes to the constitutional modifications. Constitutional changes require a two thirds majority of both Houses of Congress and additionally have to ratified by three fourths of the statesby the constitutional conventions (Art. V, cited in Willoweit, Seif, as annotation 1, pp. 275 et seq.). Compare Müßig, Die europäische Verfassungsdiskussion (as annotation 17), pp. 27 et seq.

${ }^{88}$ Libiszowska (as annotation 20), pp. 233 et seq.

${ }^{89}$ Cited in Willoweit, Seif (as annotation 1), pp. 275 et seq.

90 The opposite position may be found in Blackstone's commentaries: "Where the common law and a statute differ, the common law gives place to the statute." (W. Blackstone, Commentaries on the Laws of England, vol. 1, Introduction sect. 3 [Of the laws of England], A Facsimile of the First Edition of Oxford 1765, Chicago/London 1979, p. 89). Also see J.V. Jezierski, Parliament and People: James Wilson and Blackstone on the Nature and Location of Sovereignty, Journal of the History of Ideas 32 [1971], 95-106). The sovereignty of the Parliament (concerning the claim for sovereignty of parliament as the highes common law court in the English constitutional struggles of the $17^{\text {th }}$ century compare Müßig, Konstitutionalismus und Verfassungskonflikt, as annotation 4, pp. 48 et seq.) justifies the supremacy of the legislative branch over the judiciary.

${ }^{91}$ E.CH. Engel, Über das Wesen der amerikanischen Revolution, in: Historische Forschungen und Probleme. Festschrift Peter Rassow, published by K.E. Born, Wiesbaden 1961, p. 211; H. Arendt, On Revolution, New York 1963, p. 152; G. Wood, The Creation of the American Republik 1776-1787, New York 1972, p. 353-354; W.P. Adams, Republikanische Verfassung und bürgerliche Freiheit. Die Verfassungen und politischen Ideen der amerikanischen Revolution, Darmstadt/Neuwied 1973, pp. 138-140.

${ }^{92}$ House of Burgesses of Virginia 1764: "And if it were proper for the Parliament to impose Taxes on the Colonies at all, which the Remonstrants take Leave to think would be inconsistent with the fundamental Principles of the Constitution, the Exercise of that Power at this Time would be ruinous to Virginia." (Prologue to Revolution. Sources and Documents on the Stamp Act Crisis, 1764-1766, published by E. Morgan, Chapel Hill 1959, p. 17); Decision of Maryland 1765: »Unconstitutional and a Direct Violation of the Rights of the Freemen of this Province« (Decision of Maryland, 28. Sept. 1765, ibid., p. 53.); Decision of Massachusetts 1765: »That all Acts made, by any Power whatever, other than the General Assembly of this Province, imposing Taxes on the Inhabitants are Infringements of our inherent and unalien- 
tutional supremacy is fixed at the end of the preamble while the loophole in the American constitutional text is finally filled with the decision of Marbury v. Madison $1803 .{ }^{93}$

III. Conclusion. The reformers and the King emerge strengthened from the election of $1790,{ }^{94}$ the aristocratic old-Republicans, however, remained the dangerous opponent to constitutional reform. The reform of the purely aristocratic state parliaments which threatened to deprive the unpropertied noblemen of their political rights strengthened the old-Republican opposition lead by Hetman Rzewuski ${ }^{95}$ but was nevertheless enforced. The laws concerning the dietes of march 24, $1791^{96}$ and concerning the royal cities of April 18, $1791^{97}$ which were incorporated as Art. 3 in the May constitution were kind of an alliance between the nobility and the bourgeoisie. It was celebrated in the town halls and churches, the names of Washington and Franklin being cited quite frequently. ${ }^{98}$ At the celebrations of the enforcement of the May constitution, Washington was hailed a hero. ${ }^{99}$ On the other side, the American authors such as Thomas Jefferson praised the May constitution as an equivalent to the American constitution. From France and the Netherlands, too, positive reactions can be found, ${ }^{100}$ them being, however, unable to protect the Polish constitution from its failure due to the resistance of the separation states after

able Rights, as Men and British Subjects: and render void the most valuable Declarations of our Charter« (ibid., pp. 57).

935 U.P. (1 Cranch) 137 (1803). Compare concerning the answer to Horst Dippel already annotation 27.

94 The number of representatives was doubled.

95 Rzewuski defended the right to vote of the unpropertied nobility since they traditionally voted for the magnates who were their landlords: S. Rzewuski, Uwagi nad prawem, które by szlachcie bez posessyi activitatem na sejmikach odbierato [Remarks on the law having the effect of depriving unpropertied noblemen of their rights in the Landtag], without a place of publication 1790.

${ }^{96}$ Only those who owned land and paid taxes possessed the passive right to vote. It can be derived therefrom that it is still a nobility that mainly makes up the nation, that it is not a nation of citizens but rather a nation of land under the May constitution.

97 All inhabitants of the royal cities who were able to prove land ownership were economically and socially equivalted to the nobility and enjoyed the same privileges such as being able to elected representatives to Parliament and being allowed to accrue a noble position.

98 Libiszowska (as annotation 20), pp. 233, 242.

99 H. Stroynowski, Mowa o Konstytucyi Rzadu ustanowionej dnia trzeciego i piatego maja $1791 \ldots$ czytana ... dnia 1 lipca 1791 [Speech on the constitutional order of may 3 and 5, 1791, ... held on July 1, 1791], cited in accordance with W. Smoleński, Ostatni rok Sejmu Wielkiego [The last year of the Great Sejm], Kraków 1897, p. 11. The King, too, did not try to hide his admiration for the correspondance to Mazzei (Stanislaw August to Philip Mazzei, 17 April 1790, Mss. Ossolineum, no. 9751, p. 29; Mazzei, Selected Writings (as annotation 68), p. 327.

100 A. Czaja, Lata wielkich nadziei. Walka o reforme państwa polskiego $w$ drugiej polowie $X V I I I w$. [The years of the great hope: Struggle for the reform of the state order of Poland during the second half of the $18^{\text {th }}$ century], Warszawa 1992, pp. 258-261. 
less than two years of enforcement. Against the "French pest at the Vistula", the Russian politic of hegemony initiated the confederation of Targowica, the acceptance of the latter by the crown with the accidence of King Stanisław Augusts in July 1792 marking the end of the Polish constitution. After the second separation in January 1793, the old-estate constitutional status before the May constitution is restored under the supervision of Russia with a reintroduction of the elective kingdom which meant the restoration of the status of guarantee and of the obligation of the Sejm to restore the cardinal rights of 1768. On November 25, 1795, Stanisław August resigned. ${ }^{101}$

The reception of the American revolution in the Polish journalism during the Great or Four-Year Sejm (Sejm Wielki oder Czteroletni) 1788-1792 is a prime example of the communication of governance by means of the creation of a constitution. The birth of the May constitution is the result of competing contemporary legal perceptions of the patriotic reform powers and the old-Republican reform opponents which were influenced by the constitutional development of the United States. The journalistic endeavour of the opponents in the Sejm to gain public support illustrates the functional connection between governance and consent of the subjects. The decree of constitutional supremacy that "all consecutive resolutions of the current Reichstag are to be consistent with the constitution in all respects" (ending of the introduction) translates the way of thinking and conviction in the sense of Burkhardt into the constitutional language: the legal fixation of the political order in a positive constitution as was the Polish May constitution of 1791 communicates governance in the social context.

\section{RECONSIDERING CONSTITUTIONAL FORMATION - THE POLISH MAY CONSTITUTION 1791 AS A MASTERPIECE OF CONSTITUTIONAL COMMUNICATION}

Summary

The Polish May Constitution, formally recognized as the first constitution in Europe, differed from the American Federal Constitution of 1787 and the French Constitution of 1791 in that that it had failed to create any legitimized foundations for a pro-revolutionary or modern state. Even worse, the Polish Constitution of 1791 did

${ }^{101}$ Compare M. Drozdowski, Die Reformen des Großen Sejms in der Praxis, in: Nationale und internationale Aspekte der polnischen Verfassung vom 3. Mai 1791, published by R. Jaworski, Frankfurt a. M. and others 1993, pp. 43-53, here: p. 48; furthermore E. Rostworowski, Ostatni kròl Rzeczypospolitej. Geneza i upadek konstytucji 3 maja [The last Polish King: Development and failure of the Consitution of May 3], Warszawa 1966. 
not provide for Polish citizenship, nor did it directly articulate the principle of the equality of citizens or for political equality, or proclaimed the fundamental rights.

The manner in which American constitutionalism influenced the discussion going on during the Polish Great (4-year) Sejm 1788-1792 confirms the cultural setting of the $18^{\text {th }}$ century Poland within the European Renaissance and reflects, at the same time, certain specific features of the Polish state. The adopted American model was used for emphasizing Poland's will to remain independent of its predatory neighbours, while the events occurring during the revolution were used as a tool that served the patriotic, as well as the republican opposition, representatives. This could be best seen in the public media contemporary to the times, and it also explains the thesis that concepts such as freedom or sovereignty were not given and explicit definition, leaving, in consequence, an open space for their application to be used as deemed fit in later practice. The anchoring of the political system in the positive constitutional law was not static, either. Instead, it meant upholding a view that principles operate only with the consent of the object. The constitution becomes an "evolutionary achievement" and remains a result of the "interaction of the constitutional text, the social context, and the political practice and constitutional interpretation". Such understanding of the drafting of a constitution as a communication of the system of government takes into account the whole evolutionary nature of constitutional procedures, which subsequently order the creation, and limit the authority, of the authorities. Constitutional historiography understood exclusively institutionally is currently passing away. Neither the contemporary conception of law, expressed by way of political practicing and constitutional interpretation, nor the wording of the constitutional preamble, has an impact on the comprehension of the evolutionary character of constitutionalism. Such an approach is favoured in the research project ReConFort financed by the European Research Board, an essential element of which the Polish constitutional history is an element.

\section{UNE NOUVELLE ANALYSE DE L'ÉLABORATION DE LA CONSTITUTION. LA CONSTITUTION POLONAISE DU 3 MAI 1791 PERÇUE COMME CHEF-D'CEUVRE DE LA COMMUNICATION CONSTITUTIONNELLE}

\section{Résumé}

La constitution de mai en Pologne, formellement considérée comme la première d'Europe, est différente de la constitution fédérale des États Unis de 1787. Elle diffère également de la constitution française de 1791 car la constitution polonaise ne crée pas de bases légitimes de l'indépendance de l'État post-révolutionnaire et moderne. Or, l'acte de 1791 n'a pas institué la nationalité polonaise. Ce qu'il lui manque, ce sont les règles d'égalité entre les citoyens, exprimées en direct, les règles d'égalité politique également ainsi que la proclamation des droits principaux. La façon dont le constitutionnalisme américain influence, en Pologne, les débats menés au sujet du 
régime institué au cours de la Diète de quatre ans (de 1788 à 1792) témoigne de l'ancrage culturel de la Pologne du XVIII ${ }^{\mathrm{e}}$ siècle dans le mouvement des Lumières européen. C'est aussi le reflet de la spécificité de l'État polonais. À l'époque de la Diète de quatre ans, dans le journalisme, le modèle américain est utilisé pour mettre en valeur les aspirations visant le maintien de l'indépendance par rapport aux États voisins expansionnistes. Les évènements de la révolution ont servi par ailleurs d'outils à l'arsenal rhétorique du camp patriotique mais aussi du camp des opposants républicains de la constitution, ce qui se manifeste dans les médias publics de la période. Cela justifie la thèse portant la définition non aboutie des termes tels que: liberté, souveraineté, mais également le fait de s'ouvrir aux moyens permettant de les utiliser en pratique. L'ancrage du régime dans le droit constitutionnel positif n'est pas statique, il traduit la façon de penser et de percevoir les choses à l'époque : les règles ne peuvent fonctionner qu'avec l'accord du sujet. La constitution devient « une réussite de l'évolution » et demeure le résultat de " l'interaction du texte constitutionnel, du contexte social, de la pratique politique et de l'interprétation de la constitution ». Le fait de comprendre l'élaboration de la constitution comme une communication du système de gouvernance prend en compte la nature évolutive des procédures constitutionnelles qui mettent de l'ordre au niveau de la conception et limitation des pouvoirs. L'historiographie de la constitution entendue uniquement comme institutionnelle, disparaît. Le concept contemporain du droit, exprimé à travers la pratique politique et l'interprétation constitutionnelle ainsi que la littérature comparée influencent la compréhension du caractère évolutif du constitutionnalisme. Cette approche est représentée dans le projet de recherche ReConFort, financé par le Conseil européen de la recherche, dont l'élément essentiel est l'histoire constitutionnelle polonaise. 